\title{
sciendo
}

\section{Identifying the determinants that cause the value movements of currencies Denar, Kuna and Dinar}

\author{
Vesna Bucevska
}

Faculty of Economics, Ss. Cyril and Methodius University, Republic of Macedonia

Vesna.Bucevska@eccf.ukim.edu.mk

Goran Mojanoski

Association of Young Analysts and Researchers, Republic of Macedonia mojanoskig@gmail.com

\begin{abstract}
:
This paper aims to evaluate the relationship of real exchange rates of domestic currencies with macroeconomic variables in Macedonia, Croatia and Serbia by using econometric approaches. Macedonia is characterized by the regime of a fixed exchange rate, Croatia is characterized by a managed floating exchange rate, while Serbia is characterized by the regime of a floating exchange rate. The choice of an exchange rate regime is an important aspect of economic management, in order to ensure competitiveness, macroeconomic stability and development. Evaluation of the relationship of Croatian, Macedonian and Serbian real exchange rates is performed by employing the consistent methodology of vector error correction modelling (VECM). According to the results of the analyses of the real exchange rates on the long run, the selected independent variables have long-run causality in case of the real exchange rate of Croatian Kuna. In case of Macedonian Denar and Serbian Dinar the VECM is inappropriate.
\end{abstract}

Keywords: fiat currency, exchange rate, real exchange rate, vector error correction model.

JEL code: C01, E41.

DOI: 10.2478/crebss-2018-0015

Received: September 10, 2018

Accepted: November 16, 2018

\section{Introduction}

Real exchange rate plays a crucial role in open economy. Real exchange rate represents the relation between nominal exchange rate and prices between two countries. Real exchange rate is more complex that nominal exchange rate, because this exchange rate could be explained as number of foreign goods that could be received in exchange for domestic goods. In addition, this exchange rate represents the exchange between typical basket of goods in one country and 
typical basket of goods in another country. When in one country the real exchange rate is raising, this indicates that the goods in this country become more expensive in relation to the goods of other country. As a crucial macroeconomic variable the real exchange rate shows the international competence of the country, which means that the real exchange rate has an effect on the trade balance.

What are the determinants of the real exchange movements in different time frames is a question that should be always answered. Models of the real exchange rates (Chinn, 2006) can be classified according to which specific price is object of focus. The focus can be put over traded goods or non-traded goods.

Modeling of the exchange rate determinants as a function of economic variables can be divided in two categories (Chinn, 2006). The first category is consisted by real exchange rate models of the nominal exchange rates that are based on the assumption of sticky prices. In the second category are models that are focused on a long run real exchange rate. In this category, the long-run relationship is direct or indirect in accordance with the monetary model. Here the main hypothesis is that a long-run exchange rate is determined by domestic prices relative to foreign prices. The long-term values of the real exchange rates may change according to the changes in the world demand for the output of a given country. Increasing the relative global demand of a country's output creates a long-term real appreciation of its currency against another currency from a foreign country, which means the real exchange rate falls. The decline in the demand for products from one country causes a long-term depreciation of its currency against the foreign one, which means the real exchange rate is growing. Prediction of the effects (Faruqee, 1995) of exchange rate changes over the trade balance is difficult. If there is a lack of information regarding the shock, it may be quite misleading to view the real exchange rate as an isolated measure for external competitiveness.

Other thing that must be taken into consideration is the behavior of the real exchange rate under different nominal exchange rates, such as fixed or within narrow bands and floating exchange rate. Countries with similar or moderate inflation rate (Mussa, 1986), but two different nominal exchange rate regimes has substantial and systematic differences in the behavior of the real exchange rate regimes. Adjustments in the relative prices of the outputs of different nations, that are response of some actual or anticipated changes in economic conditions, could be one of the reasons for greater short-term variability under floating exchange rate regimes, than under fixed exchange rate regimes. The cause of greater short-term variability under floating exchange rate regimes could be because countries with fixed exchange rate regimes artificially impede necessary and desirable adjustments. Other reason for greater short-term variability of the floating exchange rate could be the differences in actual or perceived conduct of economic policies. Commitment of the authorities to the policies consistent with the maintenance of fixed nominal exchange rates plays a crucial rule in stabilizing the movements of nominal and real exchange rates under fixed exchange regime.

The paper has the following structure. Next section has more detailed literature review on this topic, and associate the author's conclusions to our contribution. Data and the econometric model are described in the Methodology section. The Results section displays the findings, and in the last section is devoted to Conclusion of the research.

\section{Literature review}

The topic of the determinants that cause the value movements of currencies has been present in literature after leaving the gold exchange standard. Countries 
began printing more of their national currency, after abandoning the gold standard. This resulted in creation of higher economic growth and higher inflation. For developing countries (Ghura, Grennes, 1993) in Sub-Saharan Africa and Latin America chronic misalignment in the real exchange rate has been a major source of slow growth.

Depending on the development of the country and its exchange regime, different determinants can cause the movement of the real exchange rate on shortrun and log-run period. Analysis of long-run determinants of USA dollar real exchange rate (Faruqee, 1995), had identified that the current and capital accounts based on country's net trade and net foreign asset positions, jointly determine the long run sustainable real exchange rate. After Broda (2004), fluctuations of the Gross Domestic Product (GDP) in developing countries with fixed regime are caused by terms of trade disturbances. In developing countries with floating regime, only $10 \%$ of the fluctuations of GDP are caused by terms of trade disturbances. This difference can be explained because of larger real exchange rate volatility that exist in floats than in pegs. Some researches indicate that the exchange rate has a key role in explaining different observed real GDP responses. In panel research of 14 SubSaharan African countries (Greenaway, Bleaney, 2001) volatility of the real exchange rate has a negative impact on investments. This panel research shows that incorporation of the trade liberalisation causes elimination of real exchange rate overvaluation.

In Serbia (Josifidis et al., 2009), current monetary and exchange rate regimes offer more discretionary space for monetary authorities to influence over the exchange rate fluctuations in idirect way via interest rate or directly through foreign exchange interventions. If the foreign currency inflow from the government borrowing is replaced with either the inflow of foreign investments or the current account surplus, than the real exchange rate could be sustainable. In Croatia (Bukovšak et al., 2017), the structure of capital flows has proved to have an important role for Kuna exchange rate developments, which should be taken into account in the future design of monetary policy instruments and macroprudential measures. In Macedonia, (Bogoev et al., 2008) the appreciation or depreciation of the real exchange rate is associated with an increase or a decrease of productivity variables.

\section{Research methodology}

This part of the paper aims to identify the variables, which cause long run movements over Croatian, Macedonian and Serbian real exchange rate? Is it possible that the same variables affect the movement of the real exchange rate of different currencies on long run, no matter of the type of the exchange rate regime? Following variables movements are examined: the index of the real exchange rate of the Dinar against the euro with the CPI deflator, the index of the real exchange rate of the Denar against the euro with the $\mathrm{CPI}$ deflator and the index of the real exchange rate of the Kuna against the euro with the CPI deflator. Variables that examine the movements of the real exchange rates in the current country are: gross reserves of the Central Bank (including gold); average paid gross salary in Euros, total monthly export in the current period, total monthly import in the current period, consumer prices index in the current period, currency in circulation, money supply M1, money supply M2.

Formally, Macedonia is characterized by a regime of fixed exchange rate, Croatia is characterized with managed floating exchange rate, while Serbia is characterized by a regime of floating exchange rate. In order to be able to identify 
the variables that affect the movements of the real exchange rates in the long run, it is necessary to create VECM models.

\section{Data}

Time series of the variables are monthly time series with 150 observations or 150 months. The analysed period is from the first month of 2004 until the sixth month of 2016. The data are taken from the Vienna Institute for International Economic Studies (2018) database.

\section{Methods}

As previously mentioned, to analyse the potential relationship between the variables we use the consistent technique of vector error correction modeling (VECM) developed by Johansen. In detail, a set of variables that have the property of nonstationarity at levels, integration of the same order and share a cointegration relationship(s), form a VECM, under which the short and long run relationships are modelled together. The advantage of VECM over other statistical methods is its consistent and robust estimates. Cointegration between two or more variables exist when their linear combination has a stationary random error. The stationarity of the error term means that the estimates are consistent, in fact "any omitted nonstationary variable that is part of the cointegrated system enters the random error thereby producing nonstationary residuals and leading to a failure to detect cointegration and producing spurious results", (Herzer, Volmer, 2012, Brooks, 2014). Additionally, if cointegration exists, then it also exists in the extended variable space, thus making VECM estimators robust to omitted variable bias (Johansen, 2000).

Formally, a Vector Error Correction Model is described with the following equation:

$$
\Delta Y_{t}=\Pi Y_{t-k}+\Gamma_{1} \Delta Y_{t-1}+\Gamma_{2} \Delta Y_{t-2}+\cdots+\Gamma_{k-1} \Delta Y_{t-(k-1)}+u_{t},
$$

where $Y_{t}=$ [agross_wages, consumer_pindex, currency, exports, gross_reserves, imports, $\mathrm{ml}$, real_exg] is a vector of dependent variables, $\Delta$ is a notation for first difference, $t$ and $k$ respectively denote time and lag; and $u_{t}$ is the error term. In Eq. (1) $\Pi$ is a matrix, in which each row forms the implicit form of a cointegration relationship among the variables, and $\Gamma_{i}$ represents the vector autoregression coefficient matrix for the $i$-th lag.

\section{Results and discussion}

All data are seasonally adjusted, using Census X-12 method. As a means to control for the potential bias due to using the current prices, a trend is added in each statistical test and equation estimation.

The first step towards estimating a cointegration, respectively a vector error correction model (VECM), is formally testing the stationarity properties of the variables. In particular, each variable should include a unit root at their level and be integrated of the same order. Testing the stationarity of real exchange rates of the currencies and other macroeconomic variables is by employing the Augmented Dickey Fuller test, (Brooks, 2014). Each variable has fixed lag length up to 13. Additionally, in each level specification is used category "None", also in the differences is used "None". Table 1 presents the results for the stationarity tests. They suggest that, at $5 \%$ significance level, all variables are nonstationary at their levels and integrated of order one. Exception was money supply $M 2$, which needs two differentiations to become stationary for each country, so this variable was excluded for the following analyses. The next step is testing the cointegration relationship between the relevant variables. 
Table 1 Stationarity test calculation

\begin{tabular}{|l|c|c|c|c|c|c|}
\hline Variable & $\begin{array}{c}\text { Level for } \\
\text { Macedonian } \\
\text { Denar }\end{array}$ & $\begin{array}{c}\text { Level for } \\
\text { Croatian } \\
\text { Kuna }\end{array}$ & $\begin{array}{c}\text { Level } \\
\text { for } \\
\text { Serbian } \\
\text { Dinar }\end{array}$ & $\begin{array}{c}\text { First } \\
\text { difference } \\
\text { for } \\
\text { Macedonian } \\
\text { Denar }\end{array}$ & $\begin{array}{c}\text { First } \\
\text { difference } \\
\text { for } \\
\text { Croatian } \\
\text { Kuna }\end{array}$ & $\begin{array}{c}\text { First } \\
\text { difference } \\
\text { for } \\
\text { Serbian } \\
\text { Dinar }\end{array}$ \\
\hline agross_wages & 3.0946 & 2.7112 & 0.4805 & -12.7123 & -8.2033 & -4.7112 \\
consumer_pindex & 0.1773 & -0.0281 & -0.2586 & -12.6072 & -11.9117 & -12.4779 \\
currency & 3.7737 & 4.0002 & 2.4683 & -14.0419 & -4.1516 & -13.7042 \\
exports & 1.3532 & 1.3306 & 2.3217 & -18.5371 & -15.1846 & -16.9021 \\
gross reserves & 1.4291 & 1.2922 & 1.0446 & -11.2370 & -14.6399 & -10.1697 \\
imports & 1.3488 & 0.6846 & 0.9173 & -13.5791 & -7.7021 & -20.9585 \\
M1 & 6.1683 & 3.3478 & 6.0059 & -4.2855 & -11.7492 & -4.1892 \\
M2 & 5.5962 & 4.9933 & 7.1834 & -1.4701 & -1.37414 & -1.0381 \\
real_exg & 0.2909 & -0.1579 & -0.1080 & -11.1633 & -11.8210 & -12.6570 \\
\hline
\end{tabular}

Notes: T- statistics for Augmented Dickey Fuller tests for each variable. In the levels, category "None" was included for each variable, also for the difference category "None" was included. Lags length was fixed to $13 .{ }^{*} \mathrm{p}<0.05$.

Source: Brooks, 2014.

Existence of cointegrating vector between the real exchange rate of the country and other variables implies that the variables share an equilibrium relationship that on the long run is independent from the short run shocks. Testing the presence of cointegration is by using Johansen cointegration tests, which differ two tests: i) the Maximum Eigenvalue; ii) Trace test, both described in Johansen.

Table 2 Cointegration tests calculation

\begin{tabular}{|l|r|r|l|}
\hline \multirow{2}{*}{ Johansen test } & \multicolumn{3}{|c|}{ Cointegration Vectors } \\
\cline { 2 - 4 } & \multicolumn{1}{|c|}{$\leq 1$} & \multicolumn{1}{c|}{$\leq 2$} & $\leq 3$ \\
\hline 1. Serbia & & & \\
Maximum Eigenvalue & 156.0397 & 111.9759 & 70.5068 \\
Trace test & 44.0637 & 41.4690 & 27.0438 \\
\hline 2. Croatia & & & \\
Maximum Eigenvalue & 146.6282 & 98.2629 & 54.9309 \\
Trace test & 48.3652 & 43.3319 & 22.8492 \\
\hline 3. Macedonia & & & \\
Maximum Eigenvalue & 132.9625 & 82.7337 & 56.1643 \\
Trace test & 50.2287 & 26.5693 & 23.5120 \\
\hline
\end{tabular}

Notes: Lag length was fixed between 1 and $4 .{ }^{*} p<0.05$.

Source: Johansen, 1988.

The statistics for all tests are shown in Table 2. At $5 \%$ significance level, both, the Maximum Eigenvalue and Trace tests indicate that there is three cointegrating vectors between the variables in case of Croatian Kuna and 2 cointegrating vectors between the variables in case of Serbian Dinar and in case of Macedonian Denar.

Since variables has unit root, they are integrated of same order and cointegrated we proceed to estimation of the vector error correction model. We study the cointegrating, long run dynamics of vector error correction model (VECM).

Table 3 provides the results for the cointegration relationship. According to the results presented in Table 2, the independent variables: gross reserves of the Central Bank (including gold); average paid gross salary in Euros, total monthly export in the current period, total monthly import in the current period, consumer prices index in the current period, currency in circulation, money supply $\mathrm{Ml}$ does not have long run causality with real exchange rates in case of Serbian Dinar and Macedonian Denar 
because $\mathrm{p}$ value is higher than 0,05 and their VEC models are not suitted. In case of vector error correction model of Croatian Kuna, the Error correction term has negative sign, also the $p$ value is smaller than 0,05 , so the independent variables jointly affects the movement of real exchange rate of Croatian Kuna.

Table 3 Vector error correction model - VECM calculation

\begin{tabular}{|l|c|c|c|}
\hline & $\begin{array}{c}\text { Real exchange } \\
\text { rate of Serbian } \\
\text { Dinar }\end{array}$ & $\begin{array}{c}\text { Real exchange } \\
\text { rate of Croatian } \\
\text { Kuna }\end{array}$ & $\begin{array}{c}\text { Real exchange } \\
\text { rate of } \\
\text { Macedonian } \\
\text { Denar }\end{array}$ \\
\hline Error correction term (ECT) & -0.3586 & -1.0213 & -0.7342 \\
p value of ECT & 0.0637 & 0.0000 & 0.0906 \\
R squared & 0.3141 & 0.5470 & 0.4862 \\
Durbin - Watson stat. & 2.0068 & 1.8674 & 2.1959 \\
\hline
\end{tabular}

Notes: Lag length was fixed between 1 and $2 .{ }^{*} p<0.05$.

Source: Johansen, 1988.

Between this real exchange rate and independent variables has long run causality. One unit of change of the independet variables, jointly will cause change of the real exchange of Croatian Kuna for 0.358629 units. The $R$ squared in the Croatian model, shows that the selected variables explain $54.7 \%$ of the movement of the real exchange rate of Croatian Kuna on a long run. Also, the R square is lower than Durbin - Watson statistic and we don't need to worry for this model that could be spurious.

\section{Conclusion}

In this paper is addressed the issue of the unknown relationship among the real exchange rates of Serbian Dinar, Croatian Kuna and Macedonian Denar and macroenomic variables in corresponding economy. This relationship is analysed by constructing a vector error correction model, especially suited for evaluating the long run dynamics of an econometric system.

According to the results of the analyses it was found out that on the long run, the selected independent variables have long run causality in case of real exchange rate of Croatian Kuna. Croatian Kuna characterized with managed floating exchange rate and one of the reason for appropriate VECM might be that in selected independent determinants has monetary determinants such as money supply M1, currency in circulation and gross reserves of the Central Bank (including gold), that can contribute in good long run model. Another reason can be stability of the consumer price index in analysed period and partial stability of the average gross wages after the world economic crises in 2008. Some other research papers for the exchange rate development of the Croatian Kuna, prove that the capital flow structure has an important role.

In case of real exchange rate of Serbian Dinar, it was found out that the selected variables create inappropriate VECM. This might be a result of the current monetary and exchange rate regime in Serbia, where monetary authorities can influence over the exchange rate fluctuations indirectly via interest rate or directly through foreign exchange interventions.

In case of real exchange rate of Macedonian Denar, the inappropriate real exchange rate VECM is outcome because in the research variables such as productivity, government consumption and openness were excluded. This variables are fairly robust in terms of sign and size. 
According to the research findings it can be concluded that different variables cause the movement of the real exchange rate on long run for different exchange rate regimes. In case of fixed exchange rates, commitment of the authorities to the policies consistent with the maintenance of fixed nominal exchange rates, plays a crucial rule in stabilizing the movements of nominal and real exchange rates under fixed exchange regime. Also, the level of economic development of the countries has an influence over the movements of the real exchange rates. Croatian economy has higher level of economic development in comparison with Macedonian and Serbian economy.

\section{References}

1. Bogoev, J., Terzijan, S. B., Egert, B., Petrovska, M. (2008). Real exchange rate dynamics in Macedonia: old wisdoms and new insights. Available at http://www.economicsejournal.org/economics/journalarticles/2008-18 [08 September 2018].

2. Broda. C. (2004). Terms of trade and exchange rate regimes in developing countries. Journal of international economics, Vol. 63. pp. 31-58.

3. Brooks. C. (2014). Introductory econometrics for finance. Cambridge university press.

4. Bukovšak, M., Cardić, G.L., Ranilović, N. (2017). Structure of capital flows and exchange rate: The case of Croatia. Available at https://www.hnb.hr/documents/20182/2030174/w052.pdf/23163f57-2b6f-4f39-81 b9-014c4304892b [08 September 2018].

5. Chinn, M. D. (2006). Real Exchange Rates. University of Wisconsin, Madison and National Bureau of Economic Research.

6. Faruqee. H. (1995). Long-run determinants of the real exchange rate: A stock flow perspective. International Monetary Fund, Staff papers, Vol. 42, No. 1, pp. 80-107.

7. Ghura, D., Grennes, T. J. (1993). The real exchange rate and macroeconomic performance in Sub-Saharan Africa. Journal of development economics, Vol. 42, pp.155174.

8. Greenaway, D., Bleaney, M. (2001). The impact of terms of trade and real exchange rate volatility on investment and growth in Sub-Saharan Africa. Journal of development economics, Vol. 65, pp. 491-500.

9. Herzer, D., Vollmer, S. (2012). Inequality and growth: evidence from panel cointegration. The Journal of Economic Inequality, Vol. 10, No. 4, pp. 489-503.

10.Johansen. S. (1988). Statistical analysis of cointegration vectors. Journal of economic dynamics and control, Vol. 12, No. 2-3, pp. 231-254.

11.Johansen. S. (2000). Modelling of cointegration in the vector autoregressive model. Economic modelling, Vol. 17, No. 3, pp. 359-373.

12.Josifidis, K., Allegret J. P., Pucar, E. B. (2009). Monetary and exchange rate regimes changer: The Cases of Poland, Czech Republic, Slovakia and Republic of Serbia. Panoeconomicus, Vol. 2. pp. 199-226.

13.Mussa. M. (1986). Nominal exchange rates regimes and the behaviour of real exchange rates: Evidence and Implications. Carnegie - Rochester Conference Series on Public Policy, Vol. 25, pp. 117-214.

14.Vienna Institute for International Economic Studies (2018). Monthly database. Available at https://data.wiiw.ac.at/monthly-database.html [08 September 2018].

\section{About the authors}

Vesna Bucevska, PhD, graduated from the Faculty of Economics in Skopje in 1993. She has been working as a Full Professor at the Faculty of Economics in Skopje since 1995 when she was elected a junior assistant of a group of subjects from the field of the statistics and econometrics. In June 1999 she defended her master thesis "Characteristics of Statistical Tests" at the Faculty of Economics of the University of Belgrade and earned the MSc Degree in Statistical Sciences. In 2000 she was elected an assistant of a group of subjects in the field of 
statistics. In June 2002 she defended her doctoral thesis "Statistical Concepts and Techniques in the Process of Quality Control and Management" and obtained a doctoral degree. In November 2002 she was elected an Assistant Professor of Econometrics and in October 2007 she was promoted and became an Associate Professor of Econometrics. Now she teaches the course Econometrics at the undergraduate level and the courses Econometric Theory, Advanced Econometrics and Statistical Quality Control in English at postgraduate studies "Statistical Methods for Business and Economics". In her tenure she published four textbooks in Macedonian and one textbook in English and six lecture and exercises notes in English and over 37 scientific-research papers in domestic and international academic journals. Author can be contacted at: vesna.bucevska@eccf.ukim.edu.mk.

Goran Mojanoski graduated from the Department of Management of the Faculty of Economics in Skopje in 2012. He started his master studies at the Department of Statistics for Business and Economy at the same Faculty in 2012. In April 2017 he defended his master thesis "Comparative analysis of relations between exchange rates and macroeconomic variables in Republic of Macedonia and Republic of Serbia - an econometric approach". Currently he is a doctoral student at the Department of Statistics for Business and Economy at the Faculty of Economics in Skopje. He is working at the Macedonian Ministry of Finance in the Financial System Department. He is also the current president of the Association of Young Analysts and Researchers, AYAR Skopje. He has published 2 research papers within AYAR Skopje and one policy paper. Also he is a co-author of scientific-research papers published in international academic journals. Author can be contacted at: mojanoskig@gmail.com. 